\title{
Pharmacognostic Standardization, Phenolic and in Vitro Antioxidant Activity of Silene villosa (Family: Caryophyllaceae)
}

\author{
Ahmed I. Foudah* \\ Department of Pharmacognosy, College of Pharmacy, Prince Sattam bin Abdulaziz University, Al-Kharj - 11942, \\ Kingdom of Saudi Arabia; a_foudah@hotmail.com
}

\begin{abstract}
The present study was designed to explore some of the quality principles and in vitro antioxidant exploration of Silene villosa "a non-intentional" herb. The pharmacognostical study and phytochemical evaluation of the herbs of S. villosa was carried out following the reported methods. The total phenolic contents and antioxidant potential of the methanol extract was also evaluated applying the standard methods. Microscopic features of the Transverse Section (T.S) of the root were observed as epidermis, medullary rays, xylem cells, phloem cells. The microscopic study of the powder showed the presence of spiral vessels, lignified fibre or tannin containing cells. The extractive value showed the water soluble materials were higher than the alcohol soluble materials. Primarily phytochemical analysis and total phenolic contents $(11.78 \pm 0.169 \%)$ in powder and extract respectively were conducted. The methanol extract of $S$. villosa showed dose dependent antioxidant activity. The present study helps in authentication of $S$. villosa and enhances further exploration of the health benefits due to the presence of phenolic contents and antioxidant property.
\end{abstract}

Keywords: Antioxidants, Pharmacognostical, Phytochemicals, Silene villosa, Total Phenols

\section{Introduction}

The Silene villosa is a therophyte plant belonging to the family Caryophyllaceae. Silene villosa is distributed in Middle East countries, South Asia and major parts of Africa ${ }^{1}$. It is wildly growing in Riyadh region of Saudi Arabia and locally known as "Terba". Except the recent study on the immunomodulation and an antioxidant of plants growing in Egypt, there is very little information on S. villosa medicinal importance ${ }^{2}$.

The Medicinal value of any plant is due to its contents from secondary metabolites ${ }^{3}$. The phytochemical analysis is the first step to explore and understand the healing properties of medicinal plants ${ }^{4}$. Pharmacognostical evaluations, i.e., macroscopic and microscopic studies are important for authentication and quality assessment of herbal materials 5 . A considerable number of plants exert antioxidant effect mainly due to the presence of plant phenols ${ }^{6}$. Antioxidants protect the human body from free radicals without creating any major toxic effects ${ }^{7}$.
In the present study the unreported, pharmacognostical, phytochemical, total phenol and antioxidant activity of $S$. villos $a$ have been explored.

\section{Materials and Methods}

\subsection{Plant Material}

S. villosa was collected in early march 2016 from Alshdeedah village- $9 \mathrm{~km}$ north of Alkharj City. The collected plant was authenticated by taxonomist Dr. M. Atiqur Rahman, from College of Pharmacy, Medicinal, Aromatic and Poisonous Plants Research Center, King Saud University, Riyadh. A voucher specimen (PSAU$\mathrm{CPH}-2-2016)$ is maintained in the herbarium of College of Pharmacy, Prince Sattam Bin Abulaziz University. The plant material was air dried and reduced to fine powder. One of fresh plant was stored in the solution containing alcohol: acetic acid: formalin mixture in the ratio of (90:5:5) for the microscopic studies.

* Author for correspondence 


\subsection{Macroscopic and Organoleptic Evaluations}

Different macroscopic parameters of stem, root, flowers and leaves as well as the organoleptic characters were investigated.

\subsection{Microscopic Evaluations}

For qualitative microscopic analysis Transverse Section (T.S) of the root was made by using sharp saving blade. Staining procedure was performed as per standard procedure $^{8}$. The whole plant powder was examined using Labomed compound microscope after clarification with chloral hydrate.

\subsection{Physico-Chemical Evaluation}

Physico-chemical parameters such as percentage of loss on drying, total ash content and extractive value were evaluated following the reported methods?

\subsection{Phytochemical Analysis}

Preliminary phytochemical study was performed using different reagents. The presence of secondary metabolites such as alkaloids, glycosides, saponins, tannins and flavonoids was identified using the standard methods ${ }^{10,12}$.

\subsection{Preparation of Methanol Extract}

Five grams of the dried powdered S. villosa was macerated with methanol for about $24 \mathrm{~h}$. The methanol extract was dried under reduced pressure using a rotary vacuum evaporator, and was used for the determination of total phenol and antioxidant potential.

\subsection{Total Phenol Contents}

Total phenolic content of methanol extracts of S. villosa was determined using Folin-Ciocalteu method, on the basis of Gallic acid calibration curve ${ }^{13}$. To prepare a calibration curve, $10 \mathrm{mg}$ of gallic acid was dissolved in $100 \mathrm{ml} 50 \%$ methanol $(100 \mu \mathrm{g} / \mathrm{ml})$ and then diluted to $6.25,12.5,25$ or $50 \mu \mathrm{g} / \mathrm{ml}$. An aliquots $1 \mathrm{ml}$ from each concentration was separately mixed with $1.5 \mathrm{ml}$ of Folin-Ciocalteu reagent and $4 \mathrm{ml}(20 \%(\mathrm{w} / \mathrm{w})$ of sodium carbonate. After incubation at $25^{\circ} \mathrm{C}$ for 30 minutes, they were measured at $765 \mathrm{~nm}$ against blank by UV-vis spectrophotometer. A similar procedure was adopted for the extracts. All determinations were carried out in triplicate. Total phenol contents $(\% \mathrm{w} / \mathrm{w})$ were calculated using the following formula:

Total phenolic contents percentage $(\% \mathrm{w} / \mathrm{w})=$ [GAE $\times \mathrm{V} \times \mathrm{D} \times 10^{-6} \times 100 / \mathrm{W}$ ],

Where, GAE - Gallic acid equivalent ( $\mu \mathrm{g} / \mathrm{ml}), \mathrm{V}$ - Total volume of sample $(\mathrm{ml})$, D-Dilution factor, W-Sample weight (g).

\subsection{DPPH Free Radical Assay}

$\mathrm{DPPH}$ free radical scavenging activity of the methanol extract of $S$. villosa was examined according to the previous method ${ }^{14}$. A small quantity of DPPH $(4 \mathrm{mg})$ was dissolved in $10 \mathrm{ml}$ methanol and it was protected from light by keeping the test tubes in the dark. For control 875 $\mu \mathrm{l}$ of methanol was mixed with $125 \mu \mathrm{l}$ of DPPH solution in a test tube. From each concentration of the extract (0.02, $0.1,0.2,1,2 \mathrm{mg} / \mathrm{ml}$ ) and ascorbic acid as a standard $500 \mu \mathrm{l}$ were taken in an Eppendorf tube separately. An accurately measured $375 \mu \mathrm{l}$ of methanol and $150 \mu \mathrm{l}$ of DPPH were added to each tube. The tubes were kept in the dark for 15 min and absorbance was taken at $517 \mathrm{~nm}$ using methanol as blank on UV/V is spectrometer. The percentage DPPH radical scavenging activity was calculated by using following formula:

Percentage DPPH radical scavenging $=\frac{A \text { control }-\mathrm{A} \text { extract }}{\mathrm{A} \text { control }} \times 100$

Where "A control" is the absorbance of control (containing all reagents without extract) and "A extract" is the absorbance of solution containing extract has been added.

\subsection{Ferric Chloride Reducing Assay}

The Ferric $\left(\mathrm{Fe}^{+3}\right)$ reducing power of methanol extracts of $S$. villosa was examined according to the method ${ }^{15}$. Different concentrations $(10,25,50,75,100 \mu \mathrm{g} / \mathrm{ml})$ of the extract were mixed with $2.5 \mathrm{ml} 0.2 \mathrm{M}$ phosphate buffer $(\mathrm{pH}$ 6.6) and $2.5 \mathrm{ml}$ of $1 \%$ potassium ferricyanide, followed by incubation at $50^{\circ} \mathrm{C}$ in a water bath for $20 \mathrm{~min}$. After incubation, $2.5 \mathrm{ml}$ of $10 \%$ Trichloroacetic Acid (TCA) was added and the mixture was centrifuged at $3000 \mathrm{rpm}$ for $10 \mathrm{~min}$. The upper layer $(2.5 \mathrm{ml})$ was mixed with $2.5 \mathrm{ml}$ de-ionized water and $0.5 \mathrm{ml} 0.1 \%$ Ferric chloride solution was added and then the absorbance was measured at $700 \mathrm{~nm}$ against an appropriate blank solution. Ascorbic acid in different concentrations $(10-100 \mu \mathrm{g} / \mathrm{ml})$ was used as a standard. The increased absorbance of the reaction mixture indicated increased reducing power. 


\subsection{Statistical Analysis}

The data were statistically analyzed as mean \pm SE. All graphs were plotted using MS office Excel ${ }^{\circ}$ software 2007. The values of correlation coefficient, intercept, slope and standard errors were obtained by nonlinear and linear regression analysis

\section{Results}

\subsection{Macroscopic and Organoleptic Characters}

Macroscopic and organoleptic characters of S. villosa are presented in Table 1. Morphological studies indicated that the leaves have opposite phyllotaxy arrangement, oblanceolate-lanceolate in shape. Lamina is fleshy and pubescent. Leaf margin is entire with acute apices. The leaves are sessile and up to $19.4 \mathrm{~mm}$, long. The size of the plants was about 20.4-30.5 cm long, with axillary buds and cyme inflorescence. The plant powder is light green in colour, coarse in touch, having unpleasant odour and slightly aromatic and disagreeable taste.

Table 1. Macroscopic characters of fresh S. villosa herbs

\begin{tabular}{lc}
\hline Physicochemical parameters & Percentage $(w / w)^{\star}$ \\
\hline Total Ash content & 2.58 \\
Moisture content & 6.94 \\
Hexane extract content & 0.45 \\
Chloroform extract content & 1.23 \\
Methanol extract content & 14.98 \\
Distilled water extract content & 25.20 \\
\hline
\end{tabular}

${ }^{\star}$ Average of $(\mathrm{n}=10)$

\subsection{Microscopic Evaluations}

The Transverse Section (T.S) of the root of S. villosa has circular outline and showed the epidermis, cortex, endodermis, medullary rays, xylem, phloem and pith Figure 1. The microscopical examination of powdered $S$. villosa whole plants showed the unique spiral and pitted vessels, lignified sclereids and lignified fibers containing ca-oxalate crystals, Figure 2 ((a)-(i)).

\subsection{Physico-Chemical Evaluation}

Table 2 showed the physicochemical parameters of powder of S. villosa plant. The total ash and moisture contents were $2.58 \%$ and $6.94 \%$ respectively. The water, methanol, chloroform and hexane soluble extractive values were $25.20 \%, 14.98 \%, 1.23 \%$, and $0.45 \%$ respectively.

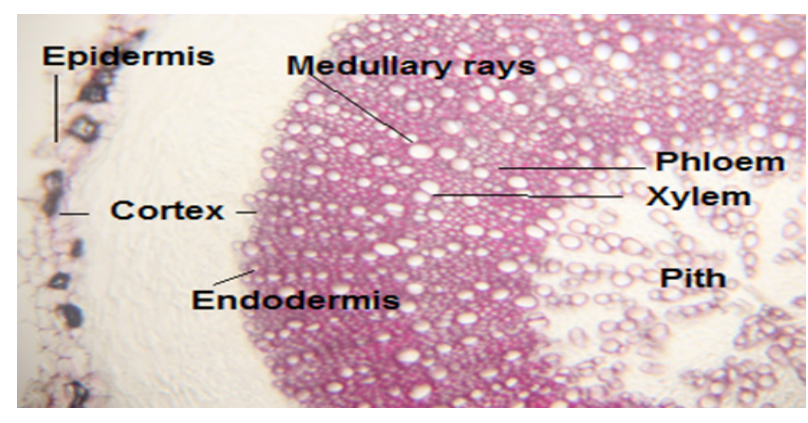

Figure 1. Microscopical view of the T. S., of the S. villosa root at $\times 20$. [Epidermis, Cortex, Endodermis, medullary rays, xylem, phloem and pith].

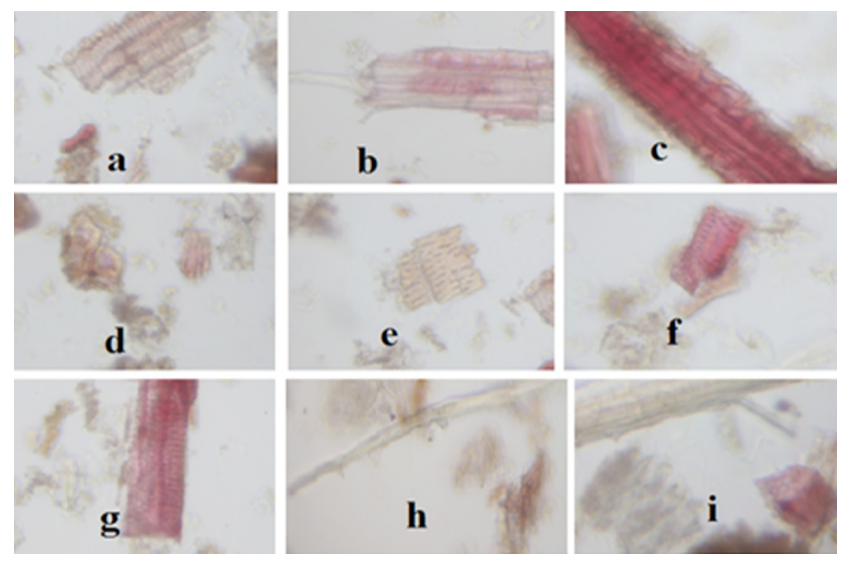

Figure 2. Powder microscopy of S. villosa. (a) spiral vessels. (b) Fibres with ca-oxalate crystals. (c) Lignified fibres. (d) Sclereids. (e) Pitted vessels (unstained). (f) Pitted vessels (stained). (g) Lignified spiral vessels. (f) single fibre unstained. (i) Lignified cells.

Table 2. Extractive values of $S$. villosa powder

\begin{tabular}{lll}
\hline S.N & Microscopic & Key structure \\
\hline 1 & Phyllotaxy & Opposite \\
2 & Lamina & Oblanceolate-Lanceolate \\
3 & Surface & Fleshy and pubescent Leaves \\
4 & Margin & Entire \\
5 & Leaf apices & Acute or Subacute \\
6 & Leaf petioles & Sessile \\
7 & Size of leaf & $19.4 \times 2.35 \mathrm{~mm}^{*}$ \\
8 & Size of plant & $20.4-30.5 \mathrm{~cm}^{*}$ \\
9 & Buds & Axillary \\
10 & Inflorescence & Cyme \\
\hline S.N & Organoleptic (powder) & Observation \\
\hline 1 & Colour & Light green \\
2 & Texture & Rough \\
3 & Odour & Characteristic \\
4 & Taste & Disagreeable \\
${ }^{*}$ Average values of leaf powdered $(\mathrm{n}=3$ )
\end{tabular}




\subsection{Phytochemical Analysis}

Phytochemical analysis showed the presence of alkaloids, sugars, glycosides, phenol and flavonoids. Comparatively the presence of saponins and carbohydrates were more intense than the other compounds in the present analysis Table 3.

Table 3. Preliminary phytochemical investigation of $S$. villosa powder

\begin{tabular}{|l|c|c|}
\hline Test & Results & Phytochemicals \\
\cline { 1 - 2 } Mayer's Test & + & \multirow{2}{*}{ Alkaloids } \\
\cline { 1 - 2 } Dragendroff's test & + & \\
\cline { 1 - 2 } Molisch's test & +++ & Carbohydrates \\
\cline { 1 - 2 } Fehling's test & +++ & \\
\cline { 1 - 2 } Modified Borntrager's Test & + & \multirow{2}{*}{ Glycosides } \\
\cline { 1 - 2 } Modified Fehling's test & + & \\
\hline Froth Test & +++ & Saponins \\
\cline { 1 - 2 } Salkowski's Test & + & \multirow{2}{*}{ Steroids and } \\
\cline { 1 - 2 } Ferric Chloride Test (10\%) & + & Phiterpenoids \\
\hline Ferric Chloride Test (1\%) & ++ & Tannins \\
\cline { 1 - 2 } Alkaline Reagent Test & + & Flavonoids \\
\cline { 1 - 2 } Lead acetate Test & ++ & \\
\cline { 1 - 2 } Ninhydrin Test & ++ & Proteins \&Aminoacids \\
\cline { 1 - 2 }
\end{tabular}

The sign $(-,+,++$ and +++$)$ for negative, slight positive and highly positive, according to appearance of colour

\subsection{Total Phenolic Contents}

Quantitative determination of total phenols was estimated by using a standard curve of gallic acid Figure 3. The analytical data of the percentage phenols content present in the methanol extract of $S$. villosa extract $(11.78 \pm 0.169$ $\%)$ was shown in Table 4.

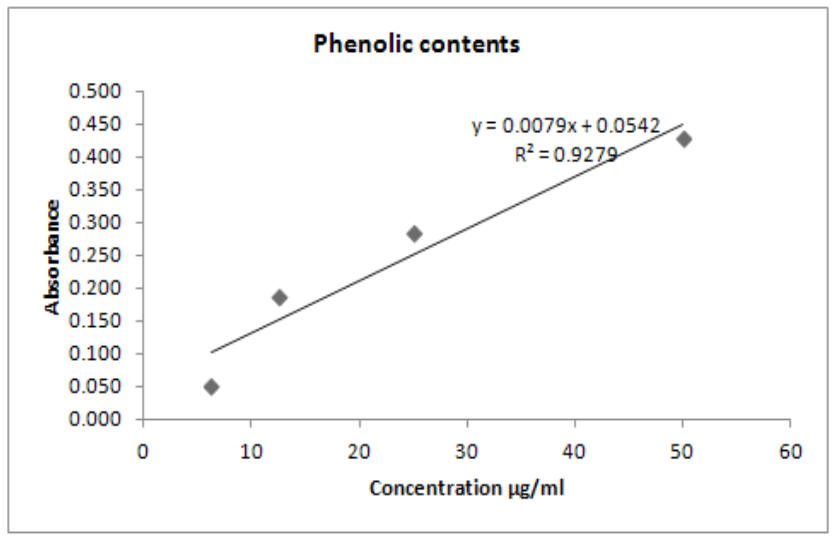

Figure 3. Standard curve of extinction against Gallic acid concentration $\mathrm{y}=0.0079 \mathrm{x}-0.0542 ; \mathrm{R}^{2}=0.9279$.
Table 4. Percentage content of total phenols in the methanol extract of $S$. villos $a$ herbs

\begin{tabular}{lc}
\hline \multicolumn{1}{c}{ Quantitative analysis } & $\begin{array}{c}\text { Percentage }(\mathrm{W} / \mathrm{W}) \\
(\text { Mean } \pm \text { SE) }\end{array}$ \\
\hline Total Phenolic contents $(\% \mathrm{w} / \mathrm{w})$ & $11.78 \pm 0.169^{*}$ \\
\hline $\mathrm{n}^{*}=3$ &
\end{tabular}

\subsection{Antioxidant Activity}

For the antioxidant assessment of $S$. villosa methanol extract the DPPH and $\mathrm{FeCl}_{3}$ reducing power methods were used and the results are presented in Figure 4 and 5 respectively. The methanol extract showed good DPPH radical-scavenging activity at a higher concentration and the activity was nearly closed to the standard (ascorbic acid) in the antioxidant assay. Similarly, in the case of $\mathrm{FeCl}_{3}$ at the higher concentration extract showed a good antioxidants, but comparatively lower than the standard (ascorbic acid).

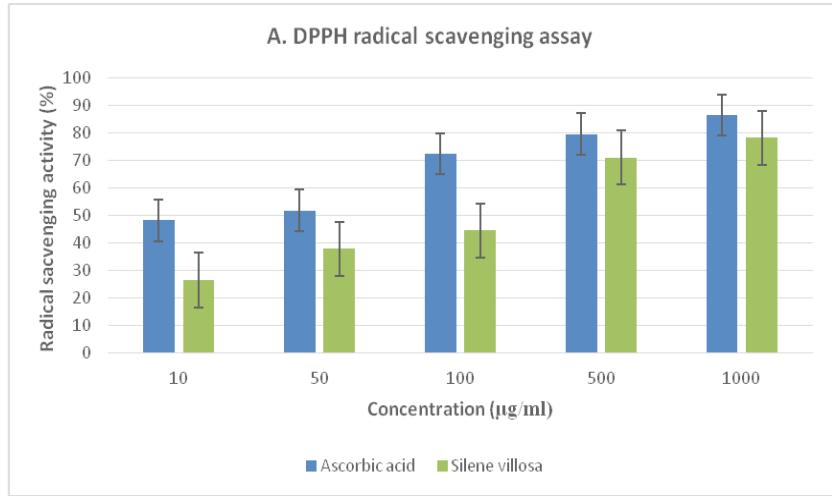

Figure 4. Radical scavenging potential of S. villosa extract by DPPH method at different concentrations $(\mu \mathrm{g} / \mathrm{ml})$.

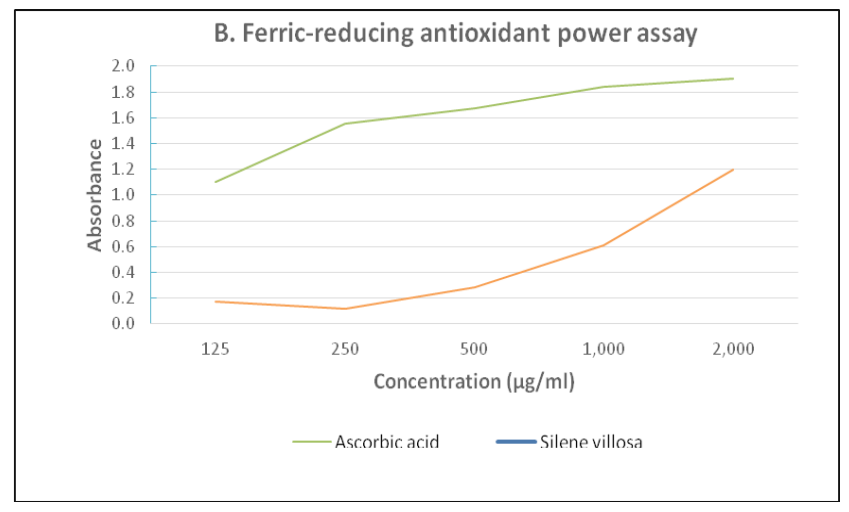

Figure 5. Ferric-reducing potential of S. villosa extract by $\mathrm{FeCl}_{3}$ method at different concentrations $(\mu \mathrm{g} / \mathrm{ml})$. 


\section{Discussion}

The result of present macroscopic and organoleptic (colour, odour, and taste) of the S. villosa herbs and its powder provides an important tools an important for identifying this plant. The authentication of the crude drug material is necessary because it maintains the quality of crude drug as well as claimed therapeutic activities ${ }^{16}$. The microscopic analysis is one of the widely used and cheapest methods for authenticating the exact raw material from the natural resources ${ }^{17}$. The Transverse Section (TS) outline of the root showed a circular outline with different layers starting with epidermis, cortex, and endodermis along with the presence of well-developed medullary rays, xylem and phloem. The physical parameters such as ash, moisture and extractive values are almost constant for each powdered drugs, therefore these findings are helpful in the standardization of a crude drug as well as essential for the detection of an adulteration. The finding of ash content is also playing a vital role in the detection of salts, elements and earth matter present in the crude powdered drugs. When the crude drug is stocked up for a longer period, there are always chances of microbial growth due to moisture present in it, hence, the low or optimum moisture content of crude drug is required for stocked ${ }^{18}$. The solvents such as hexane, chloroform, methanol and water-soluble extractive contents were determined to recognize the quantity of soluble components present in different solvent system. Higher extractive value implies that solvent is a better than the other solvents for the extraction ${ }^{19}$. In the present study water soluble extract was more than other solvents, so the higher water-soluble extractive value means that $S$. villosa is rich in polar metabolites. This fact is completely supported by intense positive results for the presence of saponins and carbohydrates during phytochemical screening. The preliminary phytochemical screening is one of the best tools for the quality assessment of the plant powder ${ }^{20}$. The analysis of the powdered drugs using different reagents is helpful in the identifications of various kinds of secondary metabolites. Apart from the other, phytochemical analysis of $S$. villosa showed the presence of phenols and flavonoids. Phenolic compounds are considered as important Phyto-constituents used for prevention of several disease conditions due to their antioxidant potential and lower side effects ${ }^{21}$. In the present finding, $S$. villosa contains a considerable amount of phenolic compounds supporting its antioxidant potential ${ }^{13}$.

\section{Conclusion}

The current study provides different tools for the identification and authentication of $S$. villosa. The phytochemical screening indicates an intense presence of saponins and carbohydrate resulted in high water extractive value. The presence of phenolic compounds in the plant explains its antioxidant potential.

\section{Acknowledgment}

The author is thankful to Mr. Aftab Alam and $\mathrm{Mr}$ Mohammad Ayman Al-Salkini, Faculty, College of Pharmacy, Prince Sattam Bin Abdulaziz University, AlKharj (KSA.) for technical assistance.

\section{Conflict of Interest Statement}

I affirm that I have no conflict of interest.

\section{References}

1. Alyemeni NM. Ecological studies on sand dunes vegetation in AI-Kharj region. Saudi J Biol Sci. 2000; 7(1):64-87.

2. Ghonime M, Emara M, Shawky R, Soliman H, El-Domany R, Abdelaziz A. Immunomodulation of RAW 264.7 murine macrophage functions and antioxidant activities of 11 plant extracts. Immunol Invest. 2015; 44 (3):237-52. PMid:25564700. https://doi.org/10.3109/08820139.2014.98 8720

3. Krishnaiah D, Sarbatly R, Bono A. Phytochemical antioxidants for health and medicine: A move towards nature. Biotechnol Mol Biol Rev. 2007; 1:97-104.

4. Ahmad M, Kaloo ZA, Ganaie BA, Ganaie HA, Singh S. Phytochemical screening of meconopsis aculeata royle an important medicinal plant of Kashmir Himalaya: A perspective. Res J Phytochem. 2016; 10:1-9.

5. Heinrich M. Ethnobotany and its role in drug development. Phytother Res. 2000; 14(7):479-88. h t t p s : / / d o i.org / $10.10002 / 1099$ 1573(200011)14:7<479::AID-PTR958>3.0.CO;2-2

6. Hertog MGI, Hollman PH, Katan MB, Kromhout D. Intake of potentially anticarcinogenic flavonoids and their determinants in adults in the Netherlands. Nutr Cancer. 1993; 20:21-9. PMid:8415127. https://doi.org/10.1080/01635589309514267

7. Osawa T, Kavakishi S, Namiki M, Kuroda Y, Shankal DM, Waters MD. Antimutagenesis and Anticarcinogenesis Mechanisms II. Plenum; New York. 1990. p. 139-53. PMid:2183766. https://doi.org/10.1007/978-1-4615-9561$8 \_11$

8. Ankad GM, Konakeri RT, Hegde HV, Roy S. Variation 
in pharmacognostic characters and polyphenolic contents among four species of medicinal plants from the genus spermacoce (Rubiaceae). Indian J Pharm Sci. 2015; 77(4):446-52. PMid:26664061ＰMCid:PMC4649792. https://doi.org/10.4103/0250-474X.164781

9. Foudah AI, Alam A, Soliman GA, Salkini MA, Yusufoglu, HS, Pharmacognostical, antibacterial and antioxidant studies of aerial parts of pulicaria somalensis (Family: Asteraceae). Asian J Biol Sci. 2016; 9:19-26. https://doi.org/10.3923/ ajbs.2016.19.26

10. Harborne JB. A guide to modern technique of plant analysis. Phytochemical Methods. London: Chapman and Hill; 1992. p. 279.

11. Sofowara EA, Medicinal plants and traditional medicine in Africa. Ibadan, Nigeria: Spectrum Books Ltd; 1993. p. 191-89.

12. Evans WC. Trease and evans pharmacognosy. 14th ed. London: WB Saunders Ltd; 1996. p. 119-59. PMid:8929253

13. Madaan R, Bansal G, Kumar S, Sharma A. Estimation of total phenols and flavonoids in extracts of actaea spicata roots and antioxidant activity studies. Indian J Pharm Sci. 2011; 73(6):666-9. PMid:23112402 PMCid:PMC3480753. https://doi.org/10.4103/0250-474X.100242

14. Barros L, Falcao S, Baptista P, Freire C, Vilas-Boas M, Ferreira IC. Antioxidant activity of Agaricus sp. mushrooms by chemical, biochemical and electrochemical assays. Food Chem. 2008; 111:61-6. https://doi.org/10.1016/j.foodchem.2008.03.033

15. Nariya PB, Bhalodia NR, Shukla VJ, Acharya R, Nariya MB. In vitro evaluation of antioxidant activity of Cordia dichotoma (Forst f.) bark. Ayu. 2013; 34(1):124-8. PMid:24049418
PMCid:PMC3764870. https://doi.org/10.4103/09748520.115451

16. Fazal H, Ahmad N, Abbasi BH. Identification, characterization, and palynologyofhigh-valuedmedicinalplants. Scientific World J. 2013:1-9. PMid:23844389 PMCid:PMC3691918 https://doi.org/10.1155/2013/283484

17. Akbar S, Hanif U, Ali J, Ishtiaq S. Pharmacognostic studies of stem, roots and leaves of Malva parviflora L. Asian Pac J Trop Biomed. 2014; 4(5):410-5. PMid:25182728 PMCid:PMC3985058. https://doi.org/10.12980/APJTB.4.2014C1107

18. Alam F, Saqib QNU. Pharmacognostic study and development of quality control parameters for fruit, bark and leaf of Zanthoxylum armatum (Rutaceae). Anc Sci Life. 2015; 34(3):147-55. PMid:26120229 PMCid:PMC4458905. https://doi.org/10.4103/0257-7941.157159

19. Ajazuddin, Saraf S. Evaluation of physicochemical and phytochemical properties of Safoof-E-Sana, a Unani polyherbal formulation. Pharmacognosy Res. 2010; 2(5):31822. PMid:21589760 PMCid:PMC3093045. https://doi. org/10.4103/0976-4836.72332

20. Chumbhale D, Upasani C. Pharmacognostic standardization of stems of Thespesia lampas (Cav.) Dalz \& Gibs. Asian Pac J Trop Biomed. 2012; 2(5):357-63. https://doi. org/10.1016/S2221-1691(12)60056-2

21. Fattahi S, Zabihi E, Abedian Z, Pourbagher R, Motevalizadeh, Ardekani A, Mostafazadeh A, Akhavan-Niaki H. Total phenolic and flavonoid contents of aqueous extract of stinging nettle and in vitro antiproliferative effect on Hela and BT-474 cell lines. Int J Mol Cell Med. 2014; 3(2):102-7. PMid:25035860 PMCid:PMC4082812. 